\title{
PREDETERMINED FOR WAR? A TRACE OF INTERGENERATIONAL TRANSMISSION OF WAR LEGACIES AMONG ETHNICALLY DIVIDED POST- WAR GENERATION FROM BOSNIAN URBAN AREAS
}

\author{
Mirza Buljubašić, PhD \\ Faculty for Criminal Justice, Criminology and Security Studies, University of Sarajevo \\ E-mail: mbuljubasic@fkn.unsa.ba
}

\begin{abstract}
Existing studies show that generations born in peace can be affected by past war(s) through intergenerational transmission (IGT) of its legacies from the generations which experienced war and often are profoundly affected by this experience (e.g. Catani, 2010). More recently, attempts have been made to extend this cycle of violence model to explain how mass atrocity violence (such as wars, genocide, or crimes against humanity) experienced by parental generations may affect the next generations (Berckmoes et al. 2017). This paper empirically explores whether war legacies (e.g. ethnic divisions) are transmitting in communities from parental (war generation) to post-war generation in Bosnia and Herzegovina and how. A brief overview of the Bosnian war (1992-1995) and clarifications regarding the IGT of mass violence stemming from various academic disciplines such as criminology, psychology, sociology, public health, anthropology, and peace and conflict studies will be presented. This research is based on a thorough qualitative study into factors of intergenerational transmission of war legacies among post-war generation from the three dominant and constituent ethnic/religious groups, former war enemies (Bosniak/Muslim, Croat/Christian and Serb/Orthodox). Focus group interviews with post-war generation have shown that relicts of the past are affecting the present and the future of the society, as well as the wellbeing of post-war generation in Bosnia and Herzegovina.
\end{abstract}

Keywords: intergenerational transmission, war, Bosnia, criminology, transitional justice

\section{Introduction}

The entire recorded human history is filled with wars (Cioffi-Revilla, 1996). Almost all known societies engaged in (occasional) warfare, but for many war was (and still is) a relatively constant element of social and human development (Keeley, 1996). Since 3600 BCE there have been only 292 years without a war recorded anywhere around the globe. Even more significantly, most wars are registered in the past two centuries (Kaarbo \& Ray, 2011, p. 183).

The last decade of the twentieth century was marked by great turmoil that followed the fall of the 'iron curtain'. It was a prelude into the twenty-first century, full of uncertainties and obscurities. The repercussions of it led to state disintegration of the Socialist Federal Republic 
of Yugoslavia (SFRY) and the large-scale atrocities. Although the war started in Slovenia and Croatia, probably the most severe casualties were seen in Bosnia and Herzegovina. Over a period of three years the conflict was brutal and resulted in many atrocities and ethnic cleansing. It is estimated that between 12,000 to 50,000 women were raped (Crowe 2014, 343). Many individuals were illegally detained in concentration camps in deplorable conditions, tortured and often killed (e.g. Omarska, Batković and Dretelj). The widespread forcible transfer of population resulted in an inevitable and irreversible change of Bosnian demographic composition. Right before the conflict ended in 1995, the Army and police of the Republika Srpska, supported by Serbian paramilitary units, entered the enclave of Srebrenica (i.e. the UN proclaimed safe haven area where many Bosniaks sought refuge during the conflict) and committed genocide. It was one of the worst atrocities on European soil since World War II (Simić \& Daly 2011). More than 8,000 individuals were shot dead by Serbian forces and paramilitaries. Only thereafter did the international community support the Croatian and Bosnian military-police operation Storm and Flash which brought about the end of the fighting and the military activities on the ground. The Bosnian conflict formally ended with the Dayton Peace Agreement concluded in December 1995 (for more details see Buljubasic \& Hola, 2019).

The absence of war, however, does not necessarily mean its total annihilation; on the contrary, legacies of war ${ }^{13}$ can remain present for decades (and even centuries) after the war (see Tyner, 2010, xiii-xv). Bosnia and Herzegovina is an exemplary case: omnipresence of war, ethnic divisions and atmosphere of permanent conflict makes the present unbearable and the future uncertain to generations that did not participate in the war or were born after the war and do not remember it (hereinafter post-war generation). ${ }^{14}$ This paper empirically explores whether war legacies (e.g. violence, ethnic divisions) are transmitting from the parental (i.e. war generation) to the post-war generation in Bosnia and Herzegovina and how. More precisely, this research explores the mere existence of IGT of war among the post-war generation and possible pathways of transmission.

Existing studies have shown that generations born in peace can be affected by past war(s) through intergenerational transmission (IGT) of its legacies from the generations which experienced the war and often are profoundly affected by this experience (e.g. Catani, 2010). In criminology, IGT refers to a phenomenon that some characteristics or behaviours can be seen both in the parent(s) and children (Besemer, 2012, p. 2). In the last decades, criminologists have studied intergenerational continuity ${ }^{15}$ in individual antisocial behaviour within families, and a substantive body of knowledge has developed on the IGT of aggressive behaviour (Doumas, et al. 1994), child maltreatment and neglect (Seay, 2016), or domestic violence (Black et al. 2010). Research conducted within the cycle of violence theory ${ }^{16}$ has made clear that antisocial and violent be-

\footnotetext{
${ }_{13}$ For the purpose of this paper, war legacies are defined as the aftermath of Bosnian war or its relicts (e.g. ethnic divisions, ethno-nationalist politics).

14 I.e., post-war generation.

15 I.e., violence begets violence or has other outcomes such as trauma.

16 I.e., cycle of violence means that violence experienced by the parental generation is passed to children.
} 
haviour is oftentimes observed within families (Widom, 1989), even over the course of multiple generations (Widom \& Wilson, 2015). More recently, attempts have been made to extend this cycle of violence model to explain how mass atrocity violence (such as wars, genocide, or crimes against humanity) experienced by parental generations may affect the next generations. Previous research on the mechanisms of IGT of mass violence was scarce and poorly understood (e.g. Cummings, et al. 2016; Betancourt, et al. 2015; Catani, 2010). More recently, studies conducted in Rwanda and Burundi confirmed profound effects of mass violence not only on individuals but also on entire families and communities (Berckmoes et al. 2017a; Berckmoes et al. 2017b). Thus, this paper will build upon previous research on the IGT mechanisms of mass violence; it aims to further the understanding of the possible pathways through which (parental/war generation) experiences of the war and its aftermath are passed to the (next) generation that did not participate in the war, was not born during the war or does not have any remembrance of it. ${ }^{17}$ To my knowledge, there is no empirical research on mechanisms of IGT of war and its aftermath in Bosnia and Herzegovina.

In order to understand how the post-war generation is affected by the war (and aftermath thereof), this research is built on Bronfenbrenner's socio-ecological model of human development. According to Bronfenbrenner (1974, see also 1979), one can interact with(in) five socio-ecological systems, each nested with the other: microsystem ${ }_{1}^{18}$ mesosystem ${ }_{1}^{19}$ exosystem ${ }_{1}^{20}$ macrosystem ${ }_{1}^{21}$ and chronosystem ${ }^{22}$ (for more detail explanation see Bronfenbrenner, 1998). Only the youth-centred perspective was employed to describe how the interviewed post-war generation experienced the legacies of the war and its aftermath.

Literature reveals that war-affected violence may transmit to the community level. Postwar generation is often affected by war legacies and confronted with various stressors in the community, such as poverty and broken social relations. Furthermore, they are embedded in the community which may shape the functioning and affect their well-being (Betancourt et al. 2015; Cummings et al. 2017). Although this paper includes multiple socio-ecological levels, it is focused especially on the community level (mesosystem) and the interactions with family and peers (microsystem and mesosystem), but also media, ethnic/religious identity/institutions and politics (macrosystem). Thus, the focus was on the process of IGT of war legacies in communities where post-war generation is inhabited and influenced primarily by the peers, but also family and wider society.

This paper is structured as follows. Section two will provide a brief description of the research methodology. The paper is based on a thorough qualitative study into factors of IGT of

\footnotetext{
17 I.e., in this paper we refer to them as post-war generation.

18 I.e.. interpersonal interactions, relationships and immediate surrounding such as family, school or peers.

19 l.e., encompasses different interactions between microsystem, such as relationship between family and community.

20 I.e., where microsystem influences or affects individual indirectly, example could be a situation when family members lose their job.

${ }^{21}$ I.e., is related to the cultural and social values and beliefs, such as religious or political influence.

22 l.e., refers to how the person and environments change over time.
} 


\section{Securitity}

war legacies among post-war generation from the three dominant and constituent ethnic/religious groups (Bosniak/Muslim, Croat/Christian and Serb/Orthodox). Interviews are the method of choice here as intergenerational (dis)continuity of war legacies is a complex process that cannot be captured or understood using other methods such as surveys. Research results and analysis will be explained in section three. The paper ends with a conclusion.

\section{Methodology}

The data used in the study were collected in five focus group interviews with undergraduate students, born in Bosnia and Herzegovina with a birth date ranging from 1990 to 1999. Thus, respondents were 18 years or older and did not have direct remembrance of the war.

The research was conducted from 17 April to 6 June 2017 at the Universities of Sarajevo, Travnik and East Sarajevo. The selected Universities are located in urban places where former war enemies had their strongholds. All participants were reached through academic networks and contacts. As suggested by Sampson (1972), the respondents were in a normal and familiar setting with sufficient space for different activities within the focus group discussion. Since a focus group discussion relies on the ability and capacity of participants to provide relevant information, purposeful sampling (Morgan, 1988) was used to identify and select adult students ${ }^{23}$ born during ${ }^{24}$ or after the war, but also to promote group interaction, and capture the diverse characteristics of participants (i.e., sex, age, living environment, ethnicity/religion, and self-reported income) (Etikan et al. 2016, p. 3; but see Patton, 2002).

Participation in focus groups was not mandatory, only respondents with intrinsic motivation/willingness to participate were asked to approach the research (see Palinkas, 2015). All the students who agreed to participate in the research signed informed consents. Krueger and Casey (2000) stated that willingness to fully engage in a group discussion is instrumental in generating useful data and can be achieved more readily within a homogenous group; participants should share similar characteristics such as age range and ethnic background. Also, mixed groups, with respect to gender, for example, tend to improve the quality of discussions and its outcomes (Freitas, 1998).

Drawing on Morgan (1996) and Coenen et al. (2012) suggestions, five focus groups were conducted. They included three ethnically homogeneous and two ethnically heterogeneous focus groups, consisting of 38 participants ( $\max =10, \min =6$ per group) from three ethnic groups: Bosniaks, Croats, Serbs, ${ }^{25}$ as well as others who had mixed ethnic background. All respondents shared similar age range - birth year from 1990 to 1999. Almost the same proportion of males $(48 \%)$ and females $(52 \%)$ were included in the sample. All respondents' nuclear family members were in Bosnia and Herzegovina during the war (for more details on the importance of homog-

\footnotetext{
23 l.e., at least 18 years old at the time of when data was collected.

24 Students born during the war were taken into consideration only on the basis of self-reported lack of war memories.

25 Please note that language, ethnicity and religion are ordered alphabetically.
} 
enous focus groups see Onwuegbuzie et al. 2009). As suggested by Onwuegbuzie et al. (2009) focus groups interviews lasted between 1 and 2 hours.

Given the sensitivity of the topic and complexity of life in a post-war setting, and since this research did not have any funding, theoretical saturation was achieved when the researcher has provided repeated evidence for conceptual categories (Bloor, et al. 2001; also see Krueger \& Casey, 2000). Glaser and Strauss (1967) introduced theoretical saturation as the point at which "no additional data are being found whereby the researcher can develop properties of the category" (p. 61). Thus, the theoretical model was developed and constantly compared against (new) incoming data (Corbin \& Strauss, 2008).

A pre-written set of open-ended questions were used to ensure flexibility during the interview. These questions were related to attitudes, feelings and behaviours on future, ${ }^{26}$ present $^{27}$ and past events/life ${ }^{28}$ in Bosnia and Herzegovina, as well as to the relation with family, siblings and community.

During the interview, the responses were audio-recorded, transcribed and subsequently content-analysed. By using original empirical data thematic analysis, a combination of both deductive (a priori) and inductive (a posteriori) coding was done. Predetermined codes were derived from the list of research open-ended questions (deductive). However, the central focus of this paper is not to test theories or set expectations using case studies, rather this study in its core is explorative and concepts, actions and meanings evolved/emerged from the data (inductive) (Stuckey, 2015). Furthermore, after the first data were collected and the accuracy of the transcripts verified, a content-driven thematic codebook, using an iterative process, was created.

\section{Results and Discussion}

This study employed a socio-ecological model of human development (and multiple system levels thereof). The overarching goal was to identify and understand whether and how war affects the post-war generation. Moreover, it explored whether embedment in the community affected the post-war generation and how.

This research is based on binominal pathways of IGT (i.e. direct and indirect) established in recent research conducted in the Rwandan postconflict society (see Berckmoes et al. 2017a; Berckmoes et al. 2017b). The indirect pathways of IGT are related to the effects of macro and meso-level of the socio-ecological model and through that post-war generation, such as dayto-day political conflicts (re-)presented in media, ethnic constitutional and institutional based divisions, interethnic distance and/or intraethnic proximity. The direct mechanisms of IGT of war legacies concern how microlevel, such as family, affects post-war generation. These pathways

\footnotetext{
26 E.g. Can you imagine Bosnia and Herzegovina as a state in which different ethnic groups live and, if so, how do they get along? Does war affect your future life, and how?

27 E.g. Would you visit or live in areas (of Bosnia and Herzegovina) that have a different cultural and traditional background than yours and, if (not) so, why?

${ }^{28}$ E.g. Do you remember the war and how? What does the war mean to you? And to your family and community?
} 
are related to the intergenerational imitation, communication ${ }^{29}$ and silence, but also labelling and generalization of other ethnic groups.

The results confirm that the effects of the war and its aftermath on post-war generation in Bosnia and Herzegovina are present and profound. The post-war generation reported that the war past shapes their present life and endangers a prosperous future (see also Berckmoes et al. 2017a). Growing up, they have learned different 'truths'30 about the war; however, its legacies and the aftermath shaped their present life. This section will describe possible pathways to IGT of war legacies among post-war generation in Bosnia and Herzegovina.

\subsection{Indirect Pathways of IGT}

Social, political and economic downfall and stagnation of the Bosnian society - from the war period until today - is persuading the post-war generation that the life in Bosnia and Herzegovina is full of pessimism. As respondents noted "in the end we have the same (lack of perspective)" (Focus group A, 27 May 2017). The reasons for the depressing state of post-war generation can be found in the poor government performance, low standard of living and the highest rate of youth unemployment in the world.

As of August 2018, Bosnia and Herzegovina has youth unemployment rate of 55.4 per cent (International Labour Organization, 2018), widespread corruption, nepotism and economic stagnation (United Nations Office on Drugs and Crime, 2011). For post-war generation, war is the cause of all these problems. They do not know "...for what greater cause ethnic groups fought for... is the outcome of the war the poverty we (inhabitants in Bosnia and Herzegovina) live in... that we are all discriminated today" (Focus group B, 25 May 2017).

The post-war generation of all ethnic groups are linked with legacies of war: sense of despair, economic hopelessness and pressures stemming from everyday political turmoil (Focus group B, 25 May 2017; Focus group C, 7 June 2017; Focus group A, 27 May 2017). Post-war generation is not only ethnically divided, they are economically, politically and socially marginalized and as such are most vulnerable to be indoctrinated by the war generation. As one respondent stressed

"Regarding the situation in Bosnia... it is very dark, it is very black, it is very monotonous... what is the consequence, is it a war? Probably it is! Is it a problem that post-war generation are spinned (by war generation) that one side (ethnic group) is not good, while the other is perfect,... whether it is up to our politicians, who are doing what they do (divide post-war generation on ethnic ground), taking what they want to take (money and goods through corruption)... and it is quite normal that post-war generation is already thinking how and planning to leave this country. In fact, many people leave the country each year..." (Focus group C, 7 June 2017).

The war established ethnic divisions and today everything revolves around ethnicity "to get a job one of the things that matters most is ethnicity... political functions are ethnically

\footnotetext{
29 E.g. altering the facts about the war.

30 There is no universal definition of truth. For the purpose of this paper, truth is defined as a fact established by domestic courts or International Criminal Tribunal for the former Yugoslavia.
} 


\section{Secuurity}

determined..." (Focus group B, 25 May 2017). As war plays a predominant role in everyday life, post-war generation is being contaminated by rigid ethno-nationalist politics. The war past is being used to such extent that it indoctrinates the generation that was not born during the war "...on a daily basis the political conflicts are based on ethnicity, religion and war... every day they (political actors) are fighting through the media" (Focus group A, 27 May 2017). Politicians in Bosnia and Herzegovina often exploit the media such as television, radio, newspapers, and internet (e.g. Facebook) to gain or maintain political power (Nešković, 2013, also see Cvjetićanin et al. 2019). Essentially, the media are a catalyst for inter-ethnic divisions among post-war generation; however, they argued that "[m]aybe it is better that they (the media)... broadcast something healthier... they (politicians) take the money, but do not poison us (post-war generation) directly." (Focus group C, 7 June 2017).

Ethnic differences and political disagreements are not the only barriers among post-war generation. Each ethnic group is in close relation with one monotheistic religion: Croats are Catholic, Serbs are Orthodox, while Bosniaks are Muslims. However, it is important to underline that many inhabitants refuse the categorization based on religious lines.

"Probably, we will all (ethnic groups) agree that we need to eat, drink, have prosperity, however, when it comes to the religion we will not get along, we will be separated..." (Focus group C, $7 \mathrm{June}$ 2017).

In general, religion is related to ethno-national identity. Both religions and ethnic identities are culturally and historically deeply intertwined to such extent that it is impossible for post-war generation to disentangle them. It is worth to note that today most Bosniaks identify as Muslims, Croats as Catholics and Serbs as (Eastern) Orthodox Christians (Census, 2013). Although many religious initiatives that connect people in Bosnia and Herzegovina exist, such as the activities of the Inter-Religious Council in the reconciliation processes in Bosnia and Herzegovina, the respondents argue that

"we (ethnic groups) are fanatic in everything... in religion... (and religion should represent) love among people, salvation, mutual tolerance... our religious fanaticism is a matter of different interpretations" (Focus group C, 7 June 2017).

Post-war generation do not share the same opinion about the three dominant (monotheistic) religions (Catholic, Islam, Orthodox). Few respondents said that religion provides positive values, while others think that it is necessary to "abolish religion, because religion is the cause of ethnic divisions (among post-war generation)" (Focus group C, 7 June 2017). The war in Bosnia and Herzegovina was not only based on ethnicity. It had religious connotations too. Hence, pathways of IGT of war are structurally conditioned and tangled (with)in ethnic and religious identities. One respondent described the situation when her friend met one boy and fell in love with him. Love was, however, short-lived:

"my friend does not like other religions, she does not like going to Sarajevo, but does not have the reason why... at one occasion she met a guy,... we told her his name is Alen... (and she replied) if 
I only knew (that he was Muslim), I would have never gotten in touch with him..." (Focus group C, 7 June 2017).

The current ethno-national and religious identities are socially and constitutionally constructed, and are a direct product of the war. The Constitution of Bosnia and Herzegovina (Annex 4 to the Dayton Peace Agreement) recognizes three constituent ethnic groups: Bosniaks, Croats and Serbs. In addition to the discriminatory provisions against other ethnic groups (e.g. Jews, Roma, Bosnians), the Constitution in itself enables and supports ethnic divisions. Although the respondents are aware of Constitutional deficiencies and its effects, they cannot change it because they think they are 'incapable' or 'powerless'. Thus, post-war generation chose to be pragmatic and entangled within one ethnic group (and war based thereof) discourses. The Constitution is a part of the Dayton Peace Agreement (Annex 4) and to disentangle the structural ethnic divisions would consequently mean to unpack the peace agreement. Accordingly, to escape "a straitjacket (i.e. ethnic, war based, divisions and stalemate) would open a Pandora's Box (i.e. unpack the peace agreement)" (Focus group A, 27 May 2017).

The war is also projected in other spheres of everyday life, for example in the education system. In Bosnia and Herzegovina, everyone can understand everyone and language differences are very small. Linguistically, Bosnia and Herzegovina shares a common language. Officially, or in the political sense, however, three languages exist (Bosnian, Croatian and Serbian) and each ethnic group invests tremendous efforts to introduce new words and change the language. Furthermore, different views on history among ethnic groups exist. Hence, the efforts to promote a different interpretation of history to be transferred to pupils through textbooks are abounding (Tveit, Cameron \& Kovač, 2014).

Textbooks for primary and secondary schools in Bosnia and Herzegovina contain fruitful content and are filled with past wars; accordingly, knowledge is systematically transferred to post-war generation.

"Did you ever read in history books, and history is life's teacher... did you find anywhere historical facts about the (football) world cup from the 1980s or Olympic games (in Bosnia and Herzegovina)... nowhere will you find positive stories in history books, everything is about war and struggle. First World War started in Bosnia, then Second World War, and not to mention Kosovo battle or other wars that took place thousands of years ago... let us change (history books), let us learn about sports, arts... in geography we have maps before wars, Bosnia before this and that war, Serbia before and after the war, Croatia back in the war days maps, war has occupied us (the post-war generation)." (Focus group A, 27 May 2017).

Textbooks contain both subtle and blatant hate speech and schools display religious symbols of the religious majority prevalent in the area where the school is located. A climate of strong tension permeates the relationship between Bosniaks and Croats. Some of the worst cases of segregation in schools take place in the two cantons of FBiH where these groups are mixed: Central Bosnia Canton and Herzegovina-Neretva Canton. There, Bosniak and Croat students attend classes in the same building but are physically separated and taught separate curricula. This system is referred to as 'two schools under one roof'. The 'two schools under one 
roof' approach not only results in separated and diversified personnel and school programs due to different ethnic belonging; it also provides a school organization where children from one ethnic group enter the school building through one specific door while children from the other ethnic group use another door, or Croatian students attend classes in the morning while Bosniaks in the afternoon (Tolomelli, 2015).

"In Central Bosnia (Central Bosnia Canton, the Federation of Bosnia and Herzegovina)... we (postwar generation) go separately (on ethnic basis) to school... our books are different... different history is written... this has to be regulated...". (Focus group C, 7 June 2017).

The war has led to a change in the demographic structure of the population in Bosnia and Herzegovina (Pejanović, 2010). As a result, most communities are ethnically homogenized or compacted, which generally affects post-war generation in various ways. Distance from the 'other(s)' and proximity within one's ethnic group shapes relations among ethnic groups equal to those that existed during the war.

"I think the problem is that the one (ethnic) majority lives in one place, they have not been in contact with other people (other ethnic groups)... they are encapsulated within (one ethnic group), therefore there is an issue with those places (where other ethnic groups live)" (Focus group A, 27 May 2017).

Several respondents, however, made it clear that difference exists when it comes to urban area communities because they tend to be ethnically heterogeneous. The respondents who live in ethnically heterogeneous communities and/or families are, to some extent, (re-)producing different (war) past images and imageries. If one lives or was born in a heterogeneous urban area, war legacies such as intolerance towards other ethnic groups could decrease. This argument can also be based solely on the assumption that heterogeneous urban areas tend to be more diverse and liberal than non-urban. In heterogeneous urban areas one can bond with other ethnic and religious groups, however, this should be taken with caution. Urban areas could also be ethnically divided. For example, Mostar is divided into places where Croats and Bosniaks live. There, youth mostly bonds in close-knit ethnically homogenized communities. Gornji Vakuf-Uskoplje is another exemplary case. It is a community and municipality in Central Bosnia (the Federation of Bosnia and Herzegovina) which is ethnically divided into Croatian and Bosniak parts. It is worth noting that the dispute about the town's name occurred during the war. Bosniaks refer to it as Cornji Vakuf, while Croats as Uskoplje. Here, the post-war generation creates the invisible 'Berlin wall' that stretches through their community

"we (Bosniaks) and they (Croats) have a line,... where my ethnic group lives and where his/her ethnicity live... (and if they cross the "line' that divides them) it is difficult... they will (members from another ethnic group) immediately figure you out and they will look at you differently (in relation to their ethnic group), like a stranger with a sense of fear and discomfort..." (Focus group A, 27 May 2017). 
The respondent also added that "in small communities it is perhaps a little harder, but in Sarajevo, I feel safe" (Focus group A, 27 May 2017). Going into or living side-by-side with other ethnically homogeneous environments or those areas that are ethnically divided is equated to a sense of uncertainty, fear and animosity. Hence, several respondents reported that they do not want to visit places where other ethnic groups live. Others, however, noted that they visit places mostly inhabited by members of ethnic groups different than theirs, but only when it comes to abundant nightlife, breath-taking beauty of nature or because it is cheaper to purchase goods and services. One respondent stressed that she "visit the dentist in Pale (East Sarajevo) because prices are lower" (Focus group D, 22 May 2017). Otherwise, visiting places inhabited by majority members of 'other' ethnic groups in Bosnia and Herzegovina can be an issue for the post-war generation.

\begin{abstract}
"I (respondent) do not have any issues with travel to the Republic of Serbia, however, it can be a problem to go to the Republika Srpska (entity of Bosnia and Herzegovina)", (Focus group B, 25 May 2017) while another respondent stated "the issue is within the other entity (the Republika Srpska)... they (Serbs) belong to 'the east' (Russia influenced countries) and we (Croats and Bosniaks) belong to the west (European Union and The North Atlantic Treaty Organization)" (Focus group B, 25 May 2017).
\end{abstract}

The post-war generation refuse to visit places they have portrayed as the territory of origin of their former war enemies; however, paradoxes exist when it comes to the neighbouring countries. For example, Bosniak post-war generation do not have a problem with visiting the neighbouring countries (the Republic of Serbia or the Republic of Croatia), although both the Republic of Serbia (see International Criminal Tribunal for the former Yugoslavia, Prosecutor v. Duško Tadić, 1997) and the Republic of Croatia (see International Criminal Tribunal for the former Yugoslavia, Prosecutor v. Prlić et al, 2017) played a major role in the Bosnian war. The respondents do not perceive the abovementioned countries as 'forbidden' territories (Focus group B, 25 May 2017). Thus, if movement within Bosnia and Herzegovina to places where members of one ethnic group are in majority presents a problem for the post-war generation, whereas movement to the neighbouring countries where the same ethnic group is in majority is not a problem, the present spatial and temporal discourse among post-war generation is divided by the same 'battle-lines' that existed during the war in the 1990s. The only difference is that the war is not the cause, rather its legacies are.

Post-war generation is not divided because they belong to a certain ethnic or religious group, it is not the case of Huntington's clash of civilizations (see Huntington, 2011), it is rather that insurmountable differences are based on the conflicting reflections and interpretations of the war past.

\title{
4.2. Direct Pathways of Transmission
}

The generations not born during the war in Bosnia and Herzegovina or not remembering it must bear with its inheritance. They are alienated from tolerance and coexistence activities and politics because they were taught by war generations to generalize and label other ethnic and 
religious groups. Thus, the present overwhelmed with the war past is not acceptable for postwar generation, it is only tolerable.

The war past - as perceived by the post-war generation - is instrumentalised and conditioned by the war generation. Moreover, interethnic distance and maintenance of war legacies stems from the influence of

"the war generation, they do not provide any opportunities for the youngsters (post-war generation)... the war generation has somehow taught the youth to be separated" (Focus group A, 27 May 2017).

The generation who experienced the war is (re-)shaping images and creating imageries of the war that started during the 1990s in Bosnia and Herzegovina and are affecting post-war generation in various ways. Through daily conversations in the family environment or among peers, distorted images or reconstructions of the past are being (re-)projected within the postwar generation. They, without any critical assessment of the past or inquiries into (ethnically) one-sided stories or silence of parents (see Kublitz, 2011), accept it as the truth (Focus group C, 7 June 2017; Focus group B, 25 May 2017). One respondent metaphorically asked a rhetorical question: "whether post-war generation is predetermined for war?" And immediately and reflexively responded that it depends mostly on

"what your (grand)parents have left for you, whether it is a crumb or a snack... whom they poisoned (with ethnic hatred derived from war past)... or if they (parents) said that the wars happened and we have to move on" (Focus group C, 7 June 2017).

Instead, to search for answers ${ }^{31}$ about facts that are related to the war past, post-war generation in Bosnia and Herzegovina developed interethnic barriers among themselves. They are refusing to accept different attitudes and perspectives that stem from the richness of Bosnian (cultural, ethnic and religious) diversity. In a nutshell, the post-war generation does not want to talk about the war with other ethnic groups: "[w]e (ethnic groups) do not have any need to discuss about that (the war) or to attach to it (the war)... we did not participate in the war" (Focus group A, 27 May 2017). The respondents do not accept or approve of opinions of members of other ethnic groups and are not able to converse rationally and liberally about common war past issues without constraints.

Dealing with the war past (e.g. a reconciliation process) is not something that is necessary for post-war generation; rather, it is an unachievable or pressured interethnic dialogue with a lowest common denominator, a theme full of inter-ethnic and religious contradictions. One of the respondents said "I (respondent) think that a conversation about the past is a taboo... I (respondent) cannot get into the discussion with someone like that (other ethnic groups in Bosnia and Herzegovina)." (Focus group B, 25 May 2017).

Although a dialogue is the first step towards reconciliation (Tint, Kalayjian \& Paloutzian, 2010), post-war generation agree that, when it comes to the war past, depending on the ethnic

31 I.e., the truth. 


\title{
Securitity
}

affiliation, they have different attitudes and opinions and should not talk about the past with other ethnic groups. "The (war) past is a taboo topic (among different ethnic groups)... we are indifferent... we do not have topics for discussion" (Focus group C, 7 June 2017).

Previous research in the field of IGT of trauma has shown that Holocaust survivors reported 'conspiracy of silence' in or disclosure by (nuclear or extended) families. Hence, trauma is mediated by the lack of open communication about the past (Danieli, 1998). In short, parental trauma experiences are thought to become a family secret which stipulates IGT of behaviour and trauma across generations (Krugman, 1987). Post-war generation in Bosnia and Herzegovina, however, do not live in 'conspiracy of silence' in families (and ethnically homogenous communities); rather, silence is a preferable option on the interethnic communal and peer-to-peer level. Thus, interethnic dialogue about the war past seems to be an issue for post-war generation. Same barriers, however, do not exist when it comes to intraethnic dialogues. Post-war generation is not

\begin{abstract}
"large-minded, they have narrow views... we (post-war generation) do not have respect toward the opinions of others (ethnic groups)... we are still cocooned (embedded or closed within one ethnic group), we go from one extreme to another... we are thought (by parental generation) to be quite, not to question (to obey and accept war legacies that stem from one ethnic group) we are indoctrinated that only mine (from one ethnic group) truth is right..." (Focus group C, 7 June 2017).
\end{abstract}

Since the war is a taboo topic for discussion between ethnic groups, post-war generation is alienated from the process of dealing with the past. It, rather, presents a (re-)production of war reminiscences, distorted and (re-)constructed memories (i.e. one-sided stories about winners and losers, perpetrators and victims) that are transmitted from the war generation to the postwar generation.

As the war past is a 'hazardous' topic (i.e. something that should not occur) in and during inter-ethnic relations and interactions, the generations that do not have any factual and direct remembrance of the war remain trapped in the 'chains' of rigid ethnic-based truths about the war. They were born free but leave an impression that they want to remain in the shackles of the war past. As one of the respondents argued "I avoid conversations about the past... everyone (other ethnicities) has an opinion on how it was (during the war)" (Focus group A, 27 May 2017). Their peers from another ethnic group agreed: "...what to talk about (the war)... we can only argue about the stories that we heard from someone (else)..." (Focus group C, 7 June 2017).

In an ethnically homogenous environment, post-war generation became ethnically more cohesive because of the war narrative (e.g. 'we are the victims', 'they committed genocide') that subsequently leads to mutual intra-ethnic support (or pressure). Thus, continuity of the war does not occur only intergenerationally, but also intragenerationally. Within one ethnic group, one war legacy feeds another (i.e. reciprocal continuity of war legacies) (Focus group E, 29 May 2017).

War legacies are also being transmitted through social bonds. More precisely, through family and peers, but also through the media and everyday ethno-nationalist politics (Focus group A, 27 May 2017; Focus group C, 7 June 2017). Accordingly, in ethnically homogenous communities, 


\section{Security}

peer pressures also stimulate continuity of war legacies from the war to the post-war generation (Focus group B, 25 May 2017). One could be indoctrinated, for example, within the family through learning or (non-)communicative processes into particularized ethnic based truths about the war, which could be subsequently confirmed through the socialization process with peers in an environment of the like-minded (i.e. ethnically homogeneous environment) (Focus group A, 27 May 2017). Consequently, ethnically driven war legacies are the only valid truth for a generation that never experienced the war or has no remembrance of it.

As it seems, the war generation does not only alter the facts about the past, it uses disingenuous, deceptive and/or manipulative tactics to reframe, reposition or otherwise modify the perception of the past (the war). Moreover, the war generation transfers selective facts or denials/quasi-apologies/minimizations of the wrongdoings of its own ethnic group to the post-war generation (Focus group E, 29 May 2017).

Distorted ethno-particularized war legacies are cultivated in the family, not only nuclear family (i.e. parents and siblings) but also extended family (i.e. grandparents, aunts and uncles), and are affecting the way in which post-war generation look at the war. As stated by a respondent:

"the youth (post-war generation) does not know exactly why they are in a dispute... what their grandmother, grandfather, mother or father told them (to post-war generation)... some hatred (ethnically or religiously based) is transmitted from a knee to knee (from generation to generation)... we (post-war generation) know nothing about the past..." (Focus group C, 7 June 2017).

From childhood to adulthood, war based ethnic 'hatred'32 and proximity is implanted in the hearts and minds of post-war generation. It is a predominant social construct that lies deep in war generations and is articulated through social bonds such as family or peers. As one of the respondents pointed out "the problem is that we (Serbs) grew up with Chetnik ${ }^{33}$ songs... they (Croats) with Thompson songs... so little ones (children) are intoxicated in that way, which is stupid" (Focus group C, 7 June 2017).

Under the influence of the dominant and extreme ethno-nationalist political discourse, post-war generation reported that homogenous ethnic environment, such as family or peers, but also the media that conveys ethno-national politics, shapes and affects their cognitive and emotional well-being (Focus group E, 29 May 2017). Hence, direct continuity of war legacies occurs primarily in the family, during everyday interaction with peers in school or elsewhere, but also by means of politicization through media 'bombardment'.

"the individuals who do not have any experience or do not remember the war (post-war generation) are driven and triggered by the issues of war past to a greater extent than the war generation... the war generation usually says things like 'never to be repeated' (the war), while we (post-war generation) act as the war is still on-going." (Focus group C, 7 June 2017).

\footnotetext{
32 As a war legacy, ethnic hatred is not an essential and inherent category.

33 Chetniks are the Serb nationalist, irredentist and royalist movement which has its influence in the Balkans (and elsewhere).
} 
Post-war generation have identified themselves with the parents' (the war generation) experience of war horrors and atrocities (Focus group E, 29 May 2017). Overwhelming suffering and horrors of mass atrocities that engulfed the families and communities of Bosnia and Herzegovina during the war are pervasive among the post-war generation and still entrenched in the current Bosnian society.

Whether the post-war generation in Bosnia and Herzegovina could become resilient to the legacies of war remains an open question, however. According to a respondent, the perfect recipe for this is to

"insert into the psyche of the new generation that it is unhealthy to condemn someone because they are of different ethnicity or religion... if it could be possible to install this into the heads of post-war generation... just as (our parents) taught us during childhood not to put our fingers in electric outlet" (Focus group C, 7 June 2017).

\section{Conclusion}

The greatest victim of the war in Bosnia and Herzegovina was (and still is) the truth. The war inevitably descended into a fog of falsehood, propaganda and mythmaking. By creating multiple deceptive truths in the daily discourse, the war generation indoctrinated (and is indoctrinating) the post-war generation in Bosnia and Herzegovina. Post-war generation is struggling with the relicts of the past that threatens the present and the future life in Bosnia. Thus, the three dominant and ethnically determined truths about the past war are coexisting (not cohabitating) in the hearts and minds of post-war generation: Bosniak, Croat, and Serb. This trichotomy of truths divided the Bosnian society into: 'us', 'them' and 'they'. What is then the genuine truth about the war in Bosnia and Herzegovina? The truth is an obscure and vague concept, cocooned in an ethnic fold and cherished as the only genuine fact and reality.

The war generation is imposing the war past as an imperative present principle of living. The post-war generation lives in the ambience and omnipresence of war not only because the war generation, peers or politicians evoke memories of war (i.e. war legacies), but also because war became a part of the system which indoctrinates the youth in Bosnia and Herzegovina. The problems of the past transcendently appear today within post-war generation, because the present is wrapped in the velvet of the past.

This qualitative study with post-war generation in Bosnia and Herzegovina aimed to understand whether war legacies are transmitted from the war generation to post-war generation to reproduce mass violence in variety of ways, and how.

Among the interviewed post-war generation, both indirect and direct mechanisms of IGT were dominant. They, on daily basis, have to face various challenges related to the past war such as poverty, interethnic distance, and extreme ethno-nationalist politics promoted through the media. Repetition of that kind, according to the Bronfenbrenner's theory on human development, "is an important condition for leaving an imprint" on the post-war generation (cited in Berckmoes, et al, 2017a, p. 13). 
For post-war generation, the present remains a collision of the war past experienced by their parents, and the distorted reality generated by members of (i.e. the war generation) their ethnic group. The post-war generation is also under the influence of ethnic war-based politics (via the media), and IGT occurs through education system, religious institutions and within communities through daily social interactions (or lack thereof). Moreover, mechanisms of transmission are in line with social learning theories such as communication or inter-ethnic silencing on the communal level.

This research, however, had unavoidable limitations. It did not capture IGT, its mechanisms or outcomes, it rather merely scratched the surface of the intergenerational processes in post-conflict Bosnia and Herzegovina. Only the respondents born from 1990 to 1999 participated in the research. The parental generation was not incorporated in this research. Only the reports from post-war generation were considered and research did not contrast/nuance reports from the parental (war) generation. Hence, no conclusive claims can be made for IGT of war (and mechanisms thereof) from the parental to the post-war generation. In addition, research results are not generalizable to the entire population. This research explored the mere existence of IGT of war among the post-war generation and possible pathways of transmission.

\section{Bibliography}

Agencija za statistiku Bosne i Hercegovine (2013). Popis stanovništva, domaćinstva i stanova u Bosni i Hercegovini/Census.

Berckmoes, L., Eichelsheim, V., Rutayisire, T., Richters, A. and Hola, B. (2017a). "How Legacies of Genocide Are Transmitted in the Family Environment: A Qualitative Study of Two Generations in Rwanda", 24 (7) Societies 3.

Berckmoes, L.H., de Jong J.T.V.M., and Reis R. (2017b). "Intergenerational transmission of violence and resilience in conflict-affected Burundi: a qualitative study of why some children thrive despite duress". Global Mental Health, 4, pp. 1-12.

Betancourt, T.S., McBain, R.K., Newnham, E.A., \& Brennan, R.T. (2015). "The intergenerational impact of war: Longitudinal relationships between caregiver and child mental health in postconflict Sierra Leone". J. Child Psychol. Psychiatry, 56, pp. 1101-1107.

Besemer, S. (2012). Intergenerational Transmission of Criminal and Violent Behaviour. Sidestone Press.

Black, D.S., Sussman, S. \& Unger, J.B. (2010). "A Further Look at the Intergenerational Transmission of Violence: Witnessing Interparental Violence in Emerging Adulthood", Journal of interpersonal violence, 25 (6), pp. 1022-1042.

Bloor, M., Frankland, J., Thomas, M., \& Robson, K. (2001). Focus groups in social research. Thousand Oaks, CA: Sage Publications Inc.

Bronfenbrenner, U. (1998). The ecology of developmental processes in: Morris, P.A. Handbook of Child Psychology, New York. pp. 993-1023.

Bronfenbrenner U. (1979). The Ecology of Human Development: Experiments by Nature and Design. Harvard University Press: Cambridge, MA. 


\section{Securitity}

Bronfenbrenner, U. (1974). Developmental research, public policy, and the ecology of childhood, Child Development, 45 (1), 1-5.

Buljubasic, M. i Hola, B. (2018). Perpetrators on trial: Characteristics of war crime perpetrators tried by courts in Bosnia and Herzegovina \& International Criminal Tribunal for the Former Yugoslavia, In: Smeulers A., Weerdesteijn M., Hola B. (eds.) Perpetrators of international crimes - methodology, theory and evidence (p.p. 273-295). Oxford University Press.

Catani, C. (2010). "War at home - a review of the relationship between War Trauma and family violence". Verhaltenstherapie, 20, pp. 19-27.

Cioffi-Revilla, C. (1996). Origins and evolution of war and politics, "International Studies Quarterly", 41(1), pp. 1-22.

Coenen, M., Coenen, T., Stamm, A., Stucki, G. \& Cieza, A. (2012). Individual interviews and focus groups in patients with rheumatoid arthritis: A comparison of two qualitative methods, Quality of Life Research, 21, pp. 359-370.

Corbin, J. \& Strauss A. (2008). Basics of Qualitative Research: Techniques and Procedures for Developing Grounded Theory. London: SAGE.

Crowe, D.M. (2014). War crimes, genocide, and justice: A global history, US: Palgrave Macmillan.

Cummings, E.M., Merrilees C.E., Taylor L.K., \& Mondi C.F. (2017). Developmental and social-ecological perspectives on children, political violence, and armed conflict. Development and Psychopathology, 29, pp. 1-10.

Cummings, E.M., Taylor L.K., Merrilees C.E., Goeke-Morey M.C., \& Shirlow P. (2016). Emotional insecurity in the family and community and youth delinquency in Northern Ireland: a person-oriented analysis across five waves. Journal of Child Psychology and Psychiatry, 57, pp. 47-54.

Cvjetićanin, T., Zulejhić, E., Brkan, D., i Livančić-Milić, B. (2019). Dezinformacije u online sferi Slučaj Bosne i Hercegovine. Udruženje građana "Zašto ne".

Danieli, Y. (1998). International handbook of multigenerational legacies of trauma. New York, NY: Springer.

Doumas, D., Margolin, G., \& Richard S.J. (1994). The intergenerational transmission of aggression across three generations, Journal of Family Violence, 9 (2), pp. 157-175.

Etikan, I., Musa, S.A., Alkassim, R.S. (2016). "Comparison of Convenience Sampling and Purposive Sampling", American Journal of Theoretical and Applied Statistics, 5(1) 1-4, p. 3.

Freitas, H., Oliveira, M., Jenkins, M., \& Popjoy, 0. (1998). "The focus group, a qualitative research method: reviewing the theory, and providing guidelines to its planning", ISRC, Merrick School of Business, University of Baltimore (MD, EUA), Working Papers ISRC No. 010298, pp. $1-22$.

Glaser, B., \& A. Strauss (1967). The Discovery of Grounded Theory: Strategies for Qualitative Research. New Brunswick, NJ: Aldine.

Huntington, S.P. (1996). The Clash of Civilizations and the Remaking of World Order, New York, Simon \& Schuster. 
International Criminal Tribunal for the former Yugoslavia (1997). Prosecutor v. Duško Tadić, Trial Judgment.

International Criminal Tribunal for the former Yugoslavia (2017). Prosecutor v. Prlić et al, Appeal Judgment.

International Labour Organization, (2018). Unemployment youth total, available here: https://data.worldbank.org/indicator/SL.UEM.1524.ZS.

Kaarbo, J. \& Ray, J.L. (2011). Global Politics. Wadsworth.

Keeley, L.H. (1996). War Before Civilization: the Myth of the Peaceful Savage. Oxford University Press.

Kellerman, N.P. (2001). Psychopathology in children of Holocaust survivors: a review of the research literature, Israel Journal for Psychiatry Relation Sciences, 38(1), pp. 36-46.

Krueger, R.A., \& Casey, M.A. (2000). Focus groups: A practical guide for applied research. Thousand Oaks, CA: Sage Publications Inc.

Krugman, S. (1987). Trauma in the family: Perspectives on the intergenerational transmission of violence. In: van der Kolk B. (eds.) Psychological. Washington, DC: American Psychiatric Publishing Inc, pp. 127-151.

Kublitz, A. (2011). The Sound of Silence: The Reproduction and Transformation of Global Conflicts within Palestinian Families in Denmark, in: Rytter, M. and Fog Olwig, K. (eds.) Mobile Bodies, Mobile Souls: Family, Religion and Migration in Global World, pp. 161-181.

Morgan, D.L. (1988). Focus group as qualitative research. Newbury Park, CA: Sage Publications Inc

Morgan, D. (1996). "Focus groups", Annual Review of Sociology 22, pp. 129-152.

Nešković, R. (2013). Nedovršena država: Politički sistem Bosne i Hercegovine. Fondacija Friedrich-Ebert Stiftung.

Onwuegbuzie, A.J., Dickinson, W.B., Leech, N.L. \& Zoran, A.G. (2009). "A Qualitative Framework for Collecting and Analyzing Data in Focus Group Research", International Journal of Qualitative Methods, 8(3), pp. 1-21.

Opći okvirni sporazum za mir u Bosni i Hercegovini (1995). Aneks 4. - Ustav Bosne i Hercegovine.

Palinkas, L.A., Horwitz, S.M., Green, C.A., Wisdom, J.P., Duan, N. \& Hoagwood, K. (2015). "Purposeful sampling for qualitative data collection and analysis in mixed method implementation research", 42 Administration and Policy in Mental Health and Mental Health Services Research, 42 (5), pp. 533-544.

Patton, M.Q. (2002). Qualitative research and evaluation methods. Thousand Oaks, CA: Sage.

Pejanović, M. (2010). Demografsko-migracijski problemi u poslijeratnoj Bosni i Hercegovini u: Markešić, I. (Eds.). Hrvati u BiH: Ustavni položaj, kulturni razvoj i nacionalni identitet. Zagreb: Centar za demokraciju i pravo Miko Tripalo i Pravni fakultet Zagreb.

Sampson, P. (1972). Qualitative research and motivation research: Consumer market research handbook. London, UK and Düsseldorf, Germany: McGraw-Hill. 


\section{Security}

Seay, D.M., Jahromi, L.B., Umaña-Taylor, A.J., \& Updegraff, K.A. (2016). "Intergenerational Transmission of Maladaptive Parenting Strategies in Families of Adolescent Mothers: Effects from Grandmothers to Young Children", Journal of Abnormal Child Psychology, 44(6), pp. 10971109.

Simić, 0. \& Daly, K. (2011). One Pair of Shoes, One Life: Steps towards Accountability for Genocide in Srebrenica. International Journal of Transitional Justice, 5, 3, pp. 477-491.

Stuckey H.L. (2015). The second step in data analysis: Coding qualitative research data. Journal of Social Health Diabetes, 3, pp. 7-10.

Tyner, J.A. (2010). Military Legacies: A World Made By War. Routledge.

Tint, B., Kalayjian, A. \& Paloutzian, R. (2010). Dialogue, Forgiveness, and Reconciliation. In: Klayjian, A. \& Paloutzian, R. Forgivness and Reconciliation. Springer, pp. 269-285.

Tveit, A.D., Cameron, D.L., and Kovač, V.B. (2014). "Two Schools under one Roof" in Bosnia and Herzegovina: Exploring the challenges of group identity and deliberative values among Bosniak and Croat students, International Journal of Educational Research, 66, pp. 103-112.

Tolomelli, A. (2015). Two schools under one roof: The role of education in the reconciliation process in Bosnia and Herzegovina, Journal of Theories and Research in Education, 10, 1 Special Issue on Religion, Conflict and Education.

United Nations Office on Drugs and Crime (2011). Corruption in Bosnia and Herzegovina: Bribery as experienced by the population. United Nations Office on Drugs and Crime.

Widom, C.S. (1989). Does violence beget violence? A critical examination of the literature. Psychological Bulletin, pp. 106, pp. 3-28.

Widom, C. S., \& Wilson, H. W. (2015). Intergenerational transmission of violence, in: Lindert, J. \& Levav, I. (eds.) Violence and mental health. Springer, Dordrecht, pp. 27-45. 